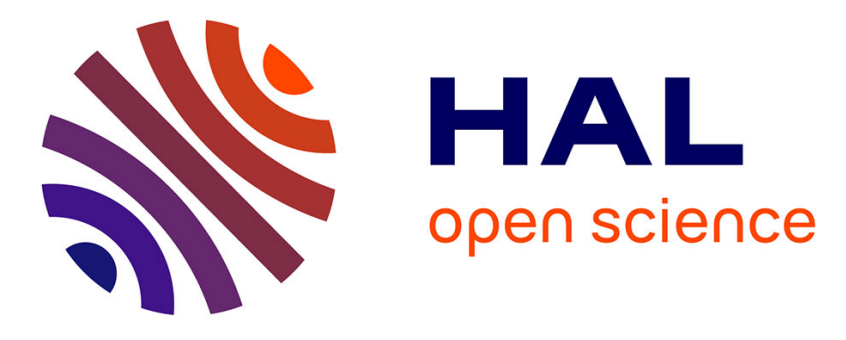

\title{
Soil microbial activity in a Mediterranean garrigue responds more to changing shrub community than to reduced rainfall
}

Nathalie Fromin, Ammar Shihan, Mathieu Santonja, Virginie Baldy, Stephan Hättenschwiler

\section{To cite this version:}

Nathalie Fromin, Ammar Shihan, Mathieu Santonja, Virginie Baldy, Stephan Hättenschwiler. Soil microbial activity in a Mediterranean garrigue responds more to changing shrub community than to reduced rainfall. Plant and Soil, 2020, 449, pp.405-421. 10.1007/s11104-020-04501-8 . hal-02521483

\section{HAL Id: hal-02521483 \\ https://hal-amu.archives-ouvertes.fr/hal-02521483}

Submitted on 28 Mar 2020

HAL is a multi-disciplinary open access archive for the deposit and dissemination of scientific research documents, whether they are published or not. The documents may come from teaching and research institutions in France or abroad, or from public or private research centers.
L'archive ouverte pluridisciplinaire HAL, est destinée au dépôt et à la diffusion de documents scientifiques de niveau recherche, publiés ou non, émanant des établissements d'enseignement et de recherche français ou étrangers, des laboratoires publics ou privés. 
1 Title: Soil microbial activity in a Mediterranean garrigue responds more to changing shrub community

2 than to reduced rainfall

3

4 Concise title: Shrub diversity impact on soil microbial functioning under reduced rainfall

5

6 Authors: Nathalie Fromin ${ }^{1} \uparrow$, Ammar Shihan ${ }^{1,2}$, Mathieu Santonja ${ }^{3}$, Virginie Baldy ${ }^{3}$, Stephan 7 Hättenschwiler ${ }^{1}$

8

$9 \quad$ Affiliations and addresses:

$10{ }^{1}$ CEFE Univ Montpellier, CNRS, EPHE, IRD, Univ Paul Valéry Montpellier 3, Montpellier, France.

$11{ }^{2}$ Department of Renewable Natural Resources and Environment, Faculty of Agricultural, Aleppo University, Aleppo, Syria

$13 \quad{ }^{3}$ Aix Marseille Univ, Avignon Université, CNRS, IRD, IMBE, Marseille, France.

$14 †$ Current address: PROMES-CNRS, 7 rue du Four Solaire, F- 66120 Odeillo (France)

15

Corresponding author: Nathalie Fromin, e-mail: nathalie.fromin@cefe.cnrs.fr , phone (+33) 4683077 46, fax: (+33) 467613336

18

Keywords: MicroResp ${ }^{\mathrm{TM}}$; functional diversity; drought; community weighted mean traits; climate 20 change; litter. 


\section{Abstract}

Aim

The functioning of soil microbial communities is co-determined by plant community composition and environmental factors. Decreased precipitation predicted in the Mediterranean area will affect both determinants, yet their interplay on soil microbial functioning is poorly understood. Here we assessed the interaction of plant community diversity and reduced precipitation on microbial metabolic activity and diversity in the topsoil of a Mediterranean shrubland in Southern France.

\section{Methods}

With a large field experiment using 92 plots that differed in the diversity of the four dominant shrub species (Quercus coccifera, Cistus albidus, Ulex parviflorus, and Rosmarinus officinalis) we manipulated the average precipitation (a mean reduction of $12 \%$ ) over three years and analyzed the community level physiological profile (MicroResp ${ }^{\mathrm{TM}}$ ) after 7 and 31 months of partial rain exclusion.

\section{Results}

Partial rain exclusion had only subtle effects on soil microbial parameters. Soil microbial global metabolic activity and diversity increased with total shrub cover but tended to decrease with shrub diversity under control conditions, relationships that were absent with partial rain exclusion. We showed strong shrub composition control over the soil microbial parameters, with a particularly strong effect of Q. coccifera.

\section{Conclusion}

Our results suggest that climate change may have greater impact on soil microbial functioning via shifts in plant community composition rather than through direct effects of reduced precipitation, yet this may depend on how precipitation will change. 


\section{Introduction}

It is well established that different plant species support contrasted soil microbial communities that drive processes at different rates (e.g. Bonkowski and Roy 2005; Lucas-Borja et al. 2012). These plant effects operate through modified environmental conditions (Augusto et al. 2015; Joly et al. 2017) or distinct quantity and/or quality of organic matter inputs through litterfall and rhizodeposition (Eviner and Chapin 2003; Bonanomi et al. 2010). Consequently, any change in the amount, quality or diversity of organic matter inputs to the soil as a result of different plant community composition is likely to have noticeable effects on the soil microbial communities and the processes they drive (Chapman and Newman 2010; Scherber et al. 2010; Strecker et al. 2015).

Many Mediterranean ecosystems are dominated by woody plants that are adapted to periodical drought and to low soil nutrient availability (De Micco and Aronne 2012; Sardans and Peñuelas 2013). These plants typically produce litter of rather low nutrient content and high concentration of structural compounds and specialized metabolites (Sardans and Peñuelas 2013). Soil moisture is commonly highly limiting during part of the year, with a strong positive correlation between soil moisture and microbial activity (Carbone et al. 2011; Schimel 2018). In these ecosystems, moisture conditions may limit soil microbial activity more than the quality of the organic carbon (C) input by litterfall (Sardans and Peñuelas 2013). The decreased precipitation of 10 to $20 \%$ annually and increased probability of more severe summer droughts predicted in the Mediterranean basin during this century (Polade et al. 2014; Lionello and Scarascia 2018) will have various effects on these ecosystems and their functioning (Peñuelas et al. 2018). But in spite of the importance of semi-arid ecosystems in the global C cycle and their role in the global C sink (Poulter et al. 2014; Ahlström et al. 2015), the response of soil processes to climate change in these ecosystems is poorly understood (Sardans \& Peñuelas 2013). Some previous studies reported limited direct effects of lower precipitation (through decreased water availability) on soil microbial parameters in semi-arid forests or shrublands (De Dato et al. 2010; Pailler et al. 2014; Curiel-Yuste et al. 2014), but indirect effects may act, especially through changes in plant physiology and in the diversity and composition of plant communities. For example, lower precipitation generally results in less litterfall production (Sardans and Peñuelas 2013, Rodríguez-Ramírez et al. 2017). The 
phenology of leaf senescence may also change as well as plant tissue quality, e.g. with projected increases in the contents of lignin and antioxidative compounds (Sardans and Peñuelas 2013). Ultimately, the most important indirect effects may be mediated by changes in plant community composition resulting from species-specific differences in drought susceptibility (Saura-Mas et al. 2012; Rodríguez-Ramírez et al. 2017), favoring more drought-resistant species (McIntyre et al. 1999; Sardans and Peñuelas 2013; Rodríguez-Ramírez et al. 2017). However, the relative contribution of these direct (decreased soil water availability) and indirect (changes in plant community composition and associated organic $\mathrm{C}$ inputs to the soil) effects on soil microbial processes and their implications for Mediterranean ecosystem functioning in a climate change context are poorly understood. Some authors suggested that the strong functional stability of soil microbial communities (Allison and Martiny 2008; Steinauer et al. 2015) and the selection of microbial phenotypes adapted to the particular Mediterranean conditions (Curiel Yuste et al. 2014) might help counteracting possible negative effects of climate change on microbial-driven ecosystem processes (Vogel et al. 2013).

In a changing environment, when conditions deviate from long term variance, plant diversity could gain in importance as a regulator of soil microbial communities and ecosystem-level processes, because of the buffering capacity of species-rich communities (Milcu et al. 2010; Santonja et al. 2015; Steinauer et al. 2015; but see Thakur et al. 2015). Because climate and biodiversity are predicted to change simultaneously, the ecosystem-level consequences could be considerable. Due to the complexity of experimental setups addressing the question of how plant diversity and climate change factors may interactively affect ecosystem functioning, relatively few studies exist (Steinauer et al. 2015; Ward et al. 2015; Santonja et al. 2017b). These data generally originate from comparatively short-term plant diversity experiments, with plant communities constructed artificially on soils that still bear legacy effects from former vegetation cover and land use, which may obscure the observed diversity effects (Eisenhauer et al. 2013).

Various characteristics of the plant community may explain how its composition and diversity links to ecosystem processes with different mechanisms at play (Cerabolini et al. 2010; Massaccesi et al. 2015; Santonja et al. 2018). First, higher plant diversity commonly means increased niche space 
filling, which in turn can lead to more efficient resource exploitation not only by the plants but also by the associated microbial community (Hooper et al. 2005; De Deyn 2013). According to the "niche complementarity hypothesis", the trait values of the species composing the community differ, resulting in functional trait divergence that may underpin plant diversity effects on ecosystem processes (Hillebrand et al. 2008; Conti and Diaz 2013). Higher niche space filling of more diverse plant communities can also result in a denser plant cover compared to communities with less species, changing microclimatic conditions (e.g. higher soil moisture) that can affect soil microbial biomass and activity (Garcia et al. 2005; Fioretto et al. 2009; Maestre et al. 2011; Chen et al. 2019). A second major mechanism for plant diversity effects is related to the relative abundance of the various species, which may contribute to a given process proportionally to their contribution to the plant community. According to the "mass ratio hypothesis" (Grime et al. 1998), the community-aggregated trait values are thought to predict plant diversity effects on ecosystem processes. Distinguishing the relative effects of these components of the plant community on ecosystem functioning is critical for a mechanistic understanding of diversity effects and their predictions (Diaz et al. 2007).

In the present study, we used an in situ experimental manipulation of precipitation in a typical Mediterranean shrubland of Southern France that consists in a series of experimental plots naturally differing in the composition of woody shrub species, and with half of the plots subjected to a partial rain exclusion. This experiment is presently the sole that addresses the interactive effects of climate change and plant diversity in naturally established plant communities. Specifically, we evaluated how the metabolic activity and diversity of soil microbial communities changed with lower precipitation depending on the plant community composition. We used 'afterlife' (leaf litter) traits of the four dominant shrub species (Quercus coccifera, Cistus albidus, Ulex parviflorus, and Rosmarinus officinalis) as functional parameters to characterize the shrub community and its effects on the soil microbial community living close to the soil surface. We measured the metabolic activity of the soil microbial community with MicroResp ${ }^{\mathrm{TM}}$, a multiple substrate-induced respiration measurement that was proposed as a robust biological indicator of soil microbial functional capacity in $\mathrm{C}$ cycling (Creamer et al. 2016). Indeed, soil microbial respiration is one of the largest fluxes of $\mathrm{CO}_{2}$ in terrestrial ecosystems 
(Bond-Lamberty and Thomson 2010). The ability of the soil microbial community to respire on a large range of substrates (referred here as 'metabolic diversity') may be critical to understand the response of soil respiration to climate change, especially in Mediterranean soils where the activity of the microbial community may be simultaneously limited by the availability of water and organic C.

We tested which of the structural (total cover and shrub diversity) or functional (aggregated leaf litter traits and their functional divergence) parameters of the shrub community relate to the metabolic properties of the soil microbial community, and whether it is modified by partial rain exclusion. In a previous study from the same field experiment, litter diversity (in terms of species richness and composition) and reduced precipitation, both had an impact on the microbial decomposer community and on the $\mathrm{C}$ and nitrogen $(\mathrm{N})$ release during litter decomposition (Santonja et al. 2017b; Shihan et al. 2017; Santonja et al. 2019). In contrast to these former studies that used a single batch of freshly fallen leaf litter exposed in field microcosms, we evaluated here the soil microbial community from undisturbed plot-specific soil with a decomposing leaf litter layer composed of different litter age cohorts and of variable species composition occurring naturally. We expected even stronger composition effects of the shrub community (in terms of both shrub species-specific cover and communityaggregated litter traits) than in the previous studies with artificially constructed mixtures of fresh-fallen leaf litter (Santonja et al. 2017b; Shihan et al. 2017; Santonja et al. 2019). According to the "niche complementarity hypothesis", we hypothesized that more diverse shrub communities are associated to (H1) more active and (H2) functionally more diverse soil microbial communities. Additionally, according to the stress-gradient hypothesis we hypothesized that $(\mathrm{H} 3)$ the relationships between shrub community and soil microbial functional parameters are modified under partial rain exclusion, with microbial communities associated to less diverse shrub communities being more affected under drier conditions.

\section{Materials and Methods}




\section{Study site and experimental rain exclusion}

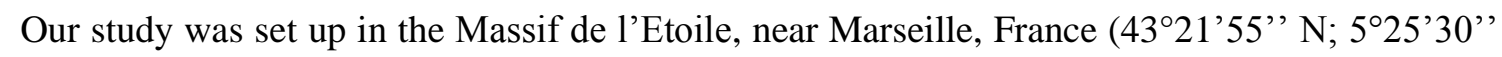
E). The site is $275 \mathrm{~m}$ above sea level with a mean annual precipitation of $570 \mathrm{~mm}$, and a mean annual temperature of $15^{\circ} \mathrm{C}$. A detailed description of the site was given by Montes et al. (2008) and Santonja et al. (2017b). The soil is classified as a shallow rendzina developed on limestone with a high percentage of stones (Montes et al. 2008) but with high heterogeneity at small spatial scale. Average texture across the experimental plots $(n=92)$ was $33.2 \pm 6.0 \%$ clay (mean \pm SE), $53.6 \pm 5.6 \%$ silt, and $13.2 \pm 2.8 \%$ sand. Total C, $\mathrm{N}$ and phosphorus (P-Olsen) contents were $95 \pm 28 \mathrm{~g} \mathrm{~kg}^{-1}, 5.30 \pm 1.30 \mathrm{~g} \mathrm{~kg}^{-1}$ and $0.025 \pm$ $0.009 \mathrm{~g} \mathrm{~kg}^{-1}$, respectively. Values of $\mathrm{pH}$ ranged from 7.22 to 8.14 with a mean of 7.73 , and cation exchange capacity from 26.4 to 65.8 with a mean value of $38.7 \mathrm{cmol} \mathrm{kg}^{-1}$ (surface $(0-5 \mathrm{~cm})$ soil characteristics for the experimental plots are shown in Table S1 Online Resource). The vegetation is a woody shrub-dominated "garrigue" with heterogeneous height (ranging from 0.2 to $1.4 \mathrm{~m}$ ) and cover (25 to 95\%) (Montes et al. 2008; Rodríguez-Ramírez et al. 2017), and with regular fires (last fire at our site occurred in 1997). A total of 27 plant species occurs at our study site, of which five dominant species accounted for $95 \%$ of the total vegetation cover (N. Rodriguez-Ramirez, personal communication). These include the four woody shrub species Quercus coccifera L. (Qc with an average cover across all plots of 36\%), Cistus albidus L. (Ca, 18\%), Ulex parviflorus Pourr. (Up, 10\%), and Rosmarinus officinalis L. (Ro, 9\%), and the grass species Brachypodium retusum P. Beauv. that accounts for $22 \%$ of the plant cover on average (see Rodríguez-Ramírez et al. 2017 for further details).

Ninety-two $4 \times 4 \mathrm{~m}$ plots were visually selected within a 2.5 ha area in order to include all possible combinations of the four dominant shrub species and their single species patches. Half of all plots, here referred to rain exclusion (RE) treatment were equipped with a rain exclusion device that consisted in a stainless-steel grid maintaining gutters $2 \mathrm{~m}$ above the ground and covering $40 \%$ of the total plot surface area. The remaining plots were assigned to a control treatment that was equipped with the same stainlesssteel grid structure, but with reversed gutters in order to keep shading and other potential side-effects of the steel structure comparable (Vogel et al. 2013). All plots were set up in October 2011. The average reduction of rainfall was $12 \pm 2 \%$ (Figure S1 Online Resource, see Santonja et al. 2019 for further 
details), which is within the range from 10 to $15 \%$ less precipitation predicted by global climate models for the region of our study site for the second half of the century (Polade et al. 2014). The amount of excluded rainfall was lower than could be expected with $40 \%$ coverage by gutters because of strong wind during rainfall events leading to lateral rainfall into the rain excluded area. The effect of rain exclusion on soil humidity was quantified using CS610 3-rod TDR probes (Campbell Scientific Ltd. Leicestershire, UK) installed at $10 \mathrm{~cm}$ soil depth in the $2 \mathrm{~m} \times 2 \mathrm{~m}$ central part of 7 control and 8 rain exclusion plots. Rain exclusion resulted in lower soil humidity ( $-6.5 \%$ on average, -13 to $-24 \%$ during rain events, Shihan et al. 2017). Additional TDR probes placed at 20 and $40 \mathrm{~cm}$ soil depth showed that the rain exclusion effect was stronger at these depths (-13 and $-22 \%$ soil water content on average from January to May 2014 in rain exclusion compared to control plots). Also, total annual precipitation can vary considerably among years, reaching $679 \mathrm{~mm}$ in 2014 that is higher than the long-term annual mean of $570 \mathrm{~mm}$ recorded at this site (Montes et al. 2008). Accordingly, the absolute and relative rain exclusion effects also vary in function of year-specific precipitation patterns (Figure S1).

\section{Plant community parameters}

We used detailed botanical surveys to estimate the local composition of the four dominant shrub species ( $C a, Q c, R o$ and $U p)$ at the plot level in summer 2012 and 2014 from the $2 \mathrm{~m} \times 2 \mathrm{~m}$ central part of each plot as their percent cover of the soil surface (Rodríguez-Ramírez et al. 2017). We did not account for B. retusum cover, because its inclusion did not improve the predictions of microbial parameters (data not shown).

We first computed the total shrub cover (ShrubCov) as the sum of the specific cover for the 4 dominant shrub species that sometimes exceed $100 \%$ when species covers are overlapping. We then used the relative cover of the four shrub species (as $\% \mathrm{Ca}, \% Q c, \%$ Ro and $\% U p$, with the sum of the four terms being equal to $100 \%$ ), and used these data to compute a Shannon diversity index as $H$ 'shrub= $-\sum_{i=1}^{4} p i * \log (p i)$, where $p i$ is the relative cover for shrub species $i$ in the plot. The chemical quality and diversity of organic input of the shrub community to the soil were estimated at the plot level as follows. Leaf litter chemical traits were determined for all four shrub species on freshly fallen leaf litter 
that was collected with litter traps from 8 individuals from each species (in monospecific situation) during summer 2011, i.e. before the installation of the rain exclusion devices (Santonja et al. 2017b; Shihan et al. 2017). The traits include total nitrogen $\left(N, \mathrm{mg} \mathrm{g}^{-1}\right)$, total phosphorus $\left(P, \mathrm{mg} \mathrm{g}^{-1}\right)$, dissolved organic $\mathrm{C}\left(D O C, \mathrm{mg} \mathrm{g}^{-1}\right)$, dissolved nitrogen (TDN, $\mathrm{mg} \mathrm{g}^{-1}$ ), lignin (Lignin, $\mathrm{mg} \mathrm{g}^{-1}$ ), and phenolics (Phenolic, $\mathrm{mg} \mathrm{g}^{-1}$ ) concentrations, as well as water holding capacity (WHC, \%), and were determined on 4 replicate subsamples of the pooled species-specific leaf litter (Table S2 Online Resource). Aggregated trait values ( $a N, a P, a D O C a T D N$, aLignin, aPhenolic, and $a W H C)$ were calculated for each individual plot as the average of species-specific litter trait values weighted by the relative cover of the shrub species using the 2012 and 2014 botanical records mentioned above, analogous to community weighted mean traits (Garnier et al. 2004). Functional trait divergence ( $f d N, f d P$, fdLignin, fdPhenolic, $f d D O C, f d T D N$, and $f d W H C$ ) was calculated for each plot as: $f d T r a i t=\sum_{i=1}^{n} \sum_{j=1}^{n} p i p j$ dij, where $p i$ and $p j$ are the relative cover for shrub species from the botanical records for the corresponding year, $i$ and $j$, and $d_{i j}$ the Euclidian distance between species $i$ and $j$ for the trait considered. As the traits considered varied considerably in their numerical value ranges, standard normal deviates were used when computing the functional divergence of traits, thus yielding an expected value of zero and a variance of one for all traits. All plant community parameters for the experimental plots in 2012 and 2014 are reported in Table S3 Online Resource.

\section{Soil sampling and microbial CLPP}

We took one soil sample from each plot using a $0.25 \times 0.25 \mathrm{~m}$ frame placed on the floor and collecting all litter and surface soil (down to 3 to $5 \mathrm{~cm}$ depth). We then extracted any macrofauna potentially present in the sample, removed the litter, and air-dried the soil at $25{ }^{\circ} \mathrm{C}$ for one week and sieved it at $2 \mathrm{~mm}$ before analyses. The first sampling was done in May 2012 (7 months after the rain exclusion started) and the second in May 2014 (31 months after the rain exclusion started). For each sampling date, the microbial analyses were performed during the following months (the dry samples were stored in a dry place in the dark). 
We used the MicroResp ${ }^{\mathrm{TM}}$ system (Macaulay Scientific Consulting, Aberdeen, UK) to characterize the metabolic parameters of the soil microbial community based on its ability to respire on various $\mathrm{C}$ substrates (potential respiration activity) (Campbell et al. 2008). About $0.300 \mathrm{~g}$ dry weight of

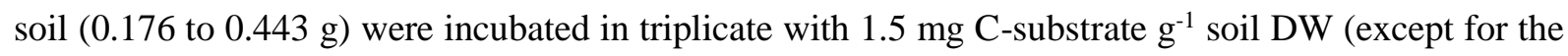
low-solubility phenolic acids and cellulose substrates for which $0.75 \mathrm{mg} \mathrm{C} \mathrm{g}^{-1}$ soil was added) using 15 different carbon substrates, plus one control with deionized water, to reach $100 \%$ of the field capacity in 96-DeepWell Microplates (Fisher Scientific E39199, Illkirch France). Carbon substrates included three carbohydrates (D-glucose, xylan, cellulose), one amine (N-acetyl-glucosamine), five amino acids (L-asparagine, L-glutamine, L-lysine, L-serine, L-glycine), three carboxylic acids (malic acid, oxalic acid, uric acid), and three phenolic acids (caffeic acid, syringic acid, vanillic acid). The latter three substrates were selected to include also more recalcitrant organic compounds. Cresol red gel detection plates were prepared as recommended by the manufacturer. After an initial two-hour pre-incubation at $25^{\circ} \mathrm{C}$ in the dark accounting for the lag period, each deepwell microplate was covered with a detection plate using a silicone gasket (MicroResp ${ }^{\mathrm{TM}}$, Aberdeen, UK): the assembly was secured with a clamp and incubated for four additional hours. Optical density at $590 \mathrm{~nm}\left(\mathrm{OD}_{590}\right)$ was measured for each detection well before and after incubation using a Victor 1420 Multilabel Counter (Perkin Elmer, Massachusetts, USA). Final $\mathrm{OD}_{590}$ were normalized using pre-incubation $\mathrm{OD}_{590}$ and converted to $\mu \mathrm{g} \mathrm{C}$ $\mathrm{CO}_{2}$ respired $\mathrm{g}^{-1}$ of soil $\mathrm{h}^{-1}$, using the average soil mass per well to weight the amount of $\mathrm{CO}_{2}$ and the headspace in which $\mathrm{CO}_{2}$ accumulated. The respiration rates for the different $\mathrm{C}$ compounds were summed across all substrates (sum15) as a proxy of the global metabolic activity, and a standardized catabolic rate was computed for each compound as the respiration rate for the specific compound divided by the total sum (sum15). A Shannon metabolic diversity index was computed as $H^{\prime} m i c=-\sum_{i=1}^{15} p i * \log (p i)$, where $p i$ is the respiration rate for substrate $i$ divided by the sum of respiration rates across the 15 substrates (sum15) for a given sample.

\section{Data analysis}


To meet the assumptions of normality of within group errors and random effects, sum 15 values

were log-transformed before any further statistical tests.

We used a multiple linear model approach ( $I m$ function from the "stats" package) to test for the effects of various parameters of the shrub community, rain exclusion, and their interactions on the soil microbial catabolic parameters (sum15 and H'mic). Four distinct models were tested in order to disentangle the effects of the different components of the shrub community. The first model tested the impact of total shrub cover ShrubCov, shrub diversity H'shrub, partial rain exclusion (control vs. rain exclusion), and their interactions. The second model tested the impact of total shrub cover ShrubCov, the relative covering of the four dominant shrub species ( $\% C a, \% Q c, \% R o$ and $\% U p)$, partial rain exclusion, and their interactions. The third and fourth models tested the impact of functional identity (aggregated traits, aTraits) or the functional diversity (functional trait divergence, fdTraits) of the plant community, respectively, partial rain exclusion and their interactions on the soil microbial parameters. For these two latter models and because of the large number of functional traits, we used the randomForest function of the eponymous package (Liaw and Wiener 2002), which classifies predictor variables by importance (Cutler et al. 2007), to select the four traits that best predicted the soil microbial parameters. To account for soil heterogeneity between plots, we included the scores of the first axis of PCA analyses of plot-specific soil characteristics (named Soil-PCA, Table S1 Online Resource) as a covariable in model fitting. These soil characteristics included texture, $\mathrm{pH}$, cation exchange capacity (CEC), and the concentrations of carbon, nitrogen, calcium, magnesium, sodium, potassium, iron, manganese, aluminum and lead (see Shihan et al. 2017 for further details).

The full models were simplified, and the most parsimonious models were determined using the stepAIC function of the "MASS" package (Venables and Ripley 2002), an established model selection procedure with both forward and backward selection algorithms, that ranks all candidate models (all possible combinations of the explanatory variables included in the full model) based on their AIC (Crawley 2013). We present the $\mathrm{R}^{2}$ and AIC values for both the full model (with all initial explanatory variables) and the most parsimonious model $(\triangle \mathrm{AIC}=0)$. 

Statistical Computing 2017) with significance levels indicated as ' for $p<0.10$, * for $p<0.05$, ** for $p$ $<0.01$, and $* * *$ for $p<0.001$.

291

\section{Results}

Seven months after the beginning of the experiment (May 2012), the ability of the soil microbial community to respire on various $\mathrm{C}$ sources (substrate induced, i.e. potential respiration rates) varied

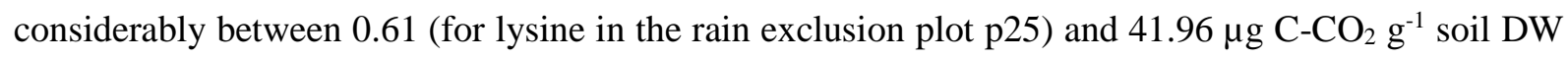
$\mathrm{h}^{-1}$ (for glucose under rain exclusion in plot p37). After 31 months (May 2014), the range was between 0.51 (for cellulose under rain exclusion in plot $\mathrm{p} 48$ ) and $31.67 \mu \mathrm{g} \mathrm{C}-\mathrm{CO}_{2} \mathrm{~g}^{-1}$ soil DW h $\mathrm{D}^{-1}$ (for $\mathrm{N}$-acetyl glucosamine in rain exclusion plot p15) (Figure 1, Table S4 Online Resource). When comparing control and rain exclusion treatments across all plots independently of their shrub species composition, substrate-induced respiration rates did not differ for any of the substrates (Figure 1), and the effects of rain exclusion or its interactions with total shrub cover or shrub diversity (H'shrub) on individual substrate respiration rates were not significant. A few individual substrate respiration rates were affected by the interaction between relative species cover and rain exclusion, but with no consistent patterns across years (data not shown).

The global metabolic activity of the soil microbial community (sum15) varied by almost a factor of 20 between 23.97 and $434.61 \mu \mathrm{g} \mathrm{C} \mathrm{g}^{-1}$ soil h$^{-1}$ in May 2012, and somewhat less between 26.90 and 376.75 $\mu \mathrm{g} \mathrm{C} \mathrm{g}^{-1}$ soil h$^{-1}$ in May 2014. There was no main effect of rain exclusion on sum15 in either year in any of the four models tested (Tables 1 to 4 ). On the contrary, there were numerous effects of shrub community structural and functional characteristics on sum15, sometimes in interaction with rain exclusion. sum15 increased with total shrub cover in May 2012 and May 2014 (Table 1) but decreased with shrub diversity H'shrub in May 2012 only under control condition (significant H'shrub $\times$ rain exclusion interaction, Table 1, Figure 2a). sum15 also responded to the composition of the shrub 
it decreased with Ro\% in May 2014 (Table 2). Regarding the effects of the plot-specific litter functional parameters, sum15 was positively related to aPhenolic and $a T D N$ in May 2012 and to $a T D N$ and $a N$ in May 2014 (Table 3). Finally, higher sum15 were recorded in plots with leaf litter exhibiting higher fdPhenolic for both years and, on the opposite, with lower fdDOC in May 2012 (Table 4).

The metabolic diversity of the soil microbial community (H'mic) ranged from 1.05 to 1.17 in May 2012 and from 1.10 to 1.18 in May 2014. As reported for sum15, there was no main effect of rain exclusion on H'mic in either year in any of the four models tested (Tables 1 to 4). H'mic was positively related to the total shrub cover ShrubCov in May 2014 only in control plots (significant ShrubCov $\times$ rain exclusion interaction, Table 1), while H'mic was negatively related to H'shrub in May 2012 only in control plots (significant $H^{\prime}$ 'shrub $\times$ rain exclusion interaction, Table 1, Figure 2b). In May 2012, H'mic was affected by the relative cover of certain shrub species, with higher H'mic when the relative cover of Quercus (Qc\%) or Ulex (Up\%, only marginally) increased (Table 2). However, we did not detect these effects in May 2014. Regarding the effects of the average plot-specific litter traits, H'mic was positively related to the average $\mathrm{N}$ content $(a N)$ in May 2012. This effect persisted in May 2014 only in control plots (significant $a N \times$ rain exclusion interaction, Table 3). Finally, H'mic was lower in plots with higher $f d D O C$ and higher in plots with higher fdPhenolic in May 2012, with no effect in May 2014 (Table 4).

Interestingly, the soil characteristics (Soil-PCA), which we included as a co-variable in all our models, generally had significant effects on soil microbial parameters and accounted for most of the explained variation in the majority of the models (Tables 1 to 4 ).

\section{Discussion}

With a total of 92 experimental plots covering a representative range of differences in shrub cover and diversity of a Mediterranean shrubland, we assessed here which plant community characteristics influence the metabolic properties of the soil microbial community, and whether partial rain exclusion changes these effects. We used the chemical composition of leaf litter (species litter traits weighted by 
342 the relative species cover) to estimate the local contribution of the shrub community to soil microbial

343 parameters at each plot. We found that several characteristics of the plant community have detectable

344 impacts on how soil microbial communities process a wide range of $\mathrm{C}$ compounds, but we observed

345 generally only small effects of partial rain exclusion (Tables 1 to 4). Overall, our statistical models including various characteristics of the shrub community explained 16 to $58 \%$ of the variability in soil microbial parameters, which is noticeable for such heterogeneous ecosystems. The importance of heterogeneity is actually well demonstrated with the consistently strong effects of the plot-specific soil physico-chemical parameters included as co-variable in our models. Despite such strong soil heterogeneity effects on soil microbial functioning, the structural and compositional differences of the shrub community had a clear impact on the functioning of soil microbial communities (Table 1 to 4 ).

\section{Shrub community diversity effects}

Following the "niche complementarity hypothesis", our first hypothesis predicted that more diverse shrub communities would promote metabolically more active soil microbial communities, through either a more abundant or chemically more diverse litter input (Chen et al. 2019). Our statistical models disentangling the respective role of total shrub cover and shrub diversity showed that both factors explained some variation in soil microbial activity. In contrast to our hypothesis, we found a lower global microbial activity (sum15) under more diverse shrub communities (Table 1). However, this relationship was significant only under control conditions and only in May 2012 (Figure 2a), indicating that such a negative relationship may not be general, and/or that mechanisms other than complementarity come into play to explain its influence on the soil microbial community. For example, plant roots may have an important role through stronger competition of a denser root system in higher diverse plant communities, which may decrease the availability of certain resources (Eviner and Chapin 2003). For instance, Wang et al. (2017) showed that species richness negatively affected the soil microbial biomass and soil basal respiration in artificial plant communities and suggested that higher root biomass production and increased competition for limiting resources were the cause. This could also be the case in our study system, where root growth for a given species is influenced by the identity of neighbors 
(Shihan et al., personal communication). Increased root competition under a more diverse shrub community could translate into qualitatively and quantitatively different allocation of photosynthates to the roots (Bessler et al. 2009) that could, in turn, impact the associated soil microbial community. However, we then would have expected stronger effects under partial rain exclusion, which was not the case. Unfortunately, we were unable to measure the contribution of root exudates or the density of root systems in our study, data that would be required for a better interpretation of the observed patterns and possibly underlying mechanisms.

According to the view that chemically more diverse organic substrates would be used more efficiently and by a more diverse microbial community (Gessner et al. 2010), we also tested for litter trait dissimilarity effects more specifically. Litter trait dissimilarity was calculated from species-specific litter traits determined from a common litter pool collected from several individuals before rain exclusion started. We acknowledge that this approach made it impossible to account for potential trait differences within species among plots or shifts in trait values following rain exclusion. However, we consider these potential differences in trait values minor compared to the important interspecific variation, which seems to be robust at our study site across different litter batches collected in different years (Coulis et al. 2013, 2015). We found that the dissimilarity in phenolics fdPhenolic was positively related to soil microbial activity (Table 4). This finding may suggest a higher activity of the microbial community when different litter species provide different amounts and/or distinct phenolic compounds such as for example by $U$. parviflorus that is relatively poor in phenolics and by $Q$. coccifera that is relatively rich in phenolics. Since we did not further characterize the specific chemistry of the phenolics it is difficult to interpret this result in more detail. On the other hand, dissimilarity in litter DOC ( $f D D O C$ ) was negatively related to sum15 in May 2012, but not in May 2014 (Table 4). Opposite to the "niche complementarity hypothesis", Pan et al. (2015) proposed that more diverse litter mixtures might reduce associated consumer biomass (and then activity) by diluting the concentration of optimal litter resources for decomposers, known as the "resource concentration hypothesis". Our results of globally negative relationship between shrub diversity and soil microbial activity (at least in May 2012, Table 1, Figure 2a) is unexpected (Chen et al. 2019) but consistent with this "resource concentration hypothesis", with 
dilution acting for particular resources such as DOC, which is a critical litter trait parameter for soil

397

398

399

400

401

402

403

404

405

406

407

408

409

410

411

412

413

414

415

416

417

418

419

420

421

microbial activity (Joly et al. 2016). The opposite effects of dissimilarity in phenolics and DOC (Table 4) are then not easy to explain and more detailed studies with a chemically more refined characterization of these groups of compounds would be needed. Such a dilution effect of optimal resources may also act for structural compounds and specialized metabolites that are typically abundant in Mediterranean plants and have inhibiting properties to microorganisms (Sardans and Peñuelas 2013; Chomel et al. 2014).

In our second hypothesis we predicted that functional microbial diversity increases with increasing plant diversity, in line with previous experiments (Carney and Matson 2005; Chapman and Newman 2010; Eisenhauer et al. 2013; Vogel et al. 2013). Indeed, a greater diversity of C inputs to the soil from a more diverse plant community may support a metabolically more diverse microbial community, then enhancing the ecosystem functions delivered by this community and their stability under changing conditions (Orwin et al. 2006). Our data did not support this hypothesis, as we observed a rather negative relationship between shrub diversity (H'shrub) and metabolic diversity (H'mic) in May 2012 and no relationship in May 2014 (Table 1, Figure 2b). In a previous experiment using the same shrub species with even litter mixtures, we found positive and negative effects of litter diversity on fungal and bacterial molecular diversity, respectively (Santonja et al. 2017b), as well as a positive correlation between shrub species richness and soil microbial metabolic diversity (Shihan et al. 2017). As stressed before, in this previous experiment fresh fallen leaf litter was used and exposed in microcosms, which cannot directly be compared with the present study. Because litter decomposition is a highly dynamic process with constantly changing litter quality and strong successional changes in the community of microbial decomposers (Chomel et al. 2014; Tlàskal et al. 2016), it is not unexpected that diversity relationships may change as well. Other studies also did not find any correlation between plant diversity and soil microbial diversity (Chodak et al. 2015; Navratilova et al. 2019). Perhaps in our study, this could be related to the negative correlation between shrub diversity and global soil microbial activity (Table 1, Figure 2a). 

parameters, with changes in the relative abundance of the four dominant shrub species leading sometimes to significant effects on soil microbial CLPPs. Specifically, higher $Q$. coccifera cover was associated to higher soil microbial activity in May 2012 (Table 2). This result is consistent with the previous experiments from the same study site that found that $Q$. coccifera litter, had particularly important effects on $\mathrm{C}$ and $\mathrm{N}$ release from decomposing litter (Santonja et al. 2019), microbial abundance within the litter (Santonja et al. 2017b), or soil microbial activity (Shihan et al. 2017). Much of this $Q$. coccifera effect may be related to the relatively high litter $\mathrm{N}$ concentrations, which were the highest among the four shrub species. A N-driven effect is corroborated by the positive effect of the presence of $U$. parviflorus on the global metabolic activity in May 2014, which as a N-fixing species also has rather high litter $\mathrm{N}$ concentration. The consistent positive effect of the $\mathrm{N}$-related parameters on soil microbial activity ( $a T D N$ in both years and aN in May 2014) and diversity ( $a N$ in May 2012) (Table 3) also supports $\mathrm{N}$ effects. Altogether, these results underline the key role of $Q$. coccifera in the functioning of the studied Mediterranean ecosystem and suggest that soil microbial metabolic diversity may be primarily influenced by the identity of the shrub species rather than by their diversity.

\section{Shrub community effects on soil microbial community under partial rain exclusion}

While soil moisture is generally considered as the most limiting factor for soil microbial activity in Mediterranean terrestrial ecosystem (Sardans and Peñuelas 2013), the moderate rain exclusion treatment applied in our experiment had only limited direct impact on soil microbial parameters (Table 1 to 4$)$. The relatively small direct effects of rain exclusion may result from the only small changes in soil water content with the partial rain exclusion compared to the control treatment $(-12 \%$ on average in surface soil). This could be a consequence of the high rock content in the soil (> 65\% of the total soil volume within the top $15 \mathrm{~cm}$ ). With the typically heavy rainfall events in the Mediterranean region, the topsoil may rapidly get saturated regardless of the rain exclusion, therefore diminishing the difference in water content of the topsoil between control and rain exclusion plots. Moreover, 2014 was a rather 'wet' year compared to the overall mean, reducing even more the absolute effect of the moderate rain 
exclusion on the soil microbial community. More generally, the apparent absence of any direct impact of lower precipitation is in line with previous studies on drought effects in Mediterranean soils, which reported no or only small effects of increased drought on the soil microbial community in forested and shrubland systems (Sardans et al. 2008; De Dato et al. 2010; Pailler et al. 2014), even in the long term (Curiel-Yuste et al. 2014). In the studied semi-arid ecosystem, the repetitive and regular summer drought may have already selected for drought-tolerant organisms, as suggested in previous studies (Evans and Wallenstein 2012; Esch et al. 2017). Consequently, ecosystems with regular drought occurrence may be less impacted by drier conditions under predicted precipitation change than ecosystems in more humid climates (Hawkes and Keitt 2015).

Nevertheless, the partial rain exclusion treatment showed some interactive effects with shrub community parameters. It is noticeable that the negative relationship between soil microbial activity or diversity and shrub diversity observed in May 2012 under control condition (Table 1, Figure 2) was absent in rain exclusion plots, possibly because lower soil moisture translated into higher soil aeration and/or root production favoring soil microbial activity. This result suggests that even relatively small changes in soil water availability can alter the impact of shrub species diversity on the soil microbial community.

Some previous studies reported interactive effects of rainfall change and plant diversity on soil microbial functional parameters (i.e. Fry et al. 2013; Santonja et al. 2017a; Pires et al. 2018). For instance, Fry et al. (2013) showed that species richness was positively related to drought resistance and rates of important ecosystem processes such as soil respiration and soil nutrient availability after 3 years of experimental rain exclusion in a successional grassland in southern England. The occurrence of such interactive effects underlines that predicting the soil microbial functioning under more severe water constraints need to consider plant diversity. Other experiments in various ecosystems, however, did not find any interactive effects of changing plant diversity and climatic conditions (such as temperature or water availability) on soil microbial biomass and microbial processes (Steinauer et al. 2015, Cedar Creek experiment, +1.5 and $+3^{\circ} \mathrm{C}$ warming on perennial grassland after 15 years; Vogel et al. 2013, Iena experiment, 2 years of summer drought increase). Also, using litter mixtures from the same four shrub 
species in equal amounts and exposed in microcosms under controlled laboratory conditions, Coulis et al. (2015) found significant effects of dryer conditions on soil microbial processes, but did not report any interactions with litter functional dissimilarity. The direction and magnitude of interactive effects of plant species diversity and climate change may also depend on the specific microbial parameters measured. In some of the studies cited above, microbial responses were measured in situ, which is different from our measurements of potential activities. These potential activities are thought to reflect the metabolic capabilities of the soil microbial community, and MicroResp ${ }^{\mathrm{TM}}$ assays have demonstrated their strength in discriminating among microbial communities across a wide range of soil and land use types (e.g. Creamer et al. 2016). In any case, it is methodologically not possible to determine the use of a range of different substrates differently than as potential activities. The way forward in future studies may be to combine a wide range of microbial measurements including both, realized activities in situ, and potential activities under standardized conditions for a more comprehensive understanding of microbial responses to a combined change in plant diversity and climatic conditions.

\section{Conclusion}

The small direct effects of partial rain exclusion on the soil microbial metabolic activity and diversity we found here support the idea that microbial communities in Mediterranean soils are particularly adapted and resistant to recurrent drought (Curiel-Yuste et al. 2014). Admittedly, the amount of excluded rainfall was relatively small, and stronger reductions or longer drought periods may have different effects. From our data we conclude that climate change may have a far greater impact on microbial functioning via shifts in plant community composition than through direct effects of decreased precipitation. At our study site we observed a particularly important role of $Q$. coccifera in determining the global metabolic activity and diversity of soil microbial communities possibly inferred to comparatively high $\mathrm{N}$ inputs. With ongoing climate change the relative contribution of this key species in the community may shift. Indeed, repetitive surveys of community composition in our rain exclusion experimental site indicated that reduced precipitation favor the more drought-resistant species, $Q$. 
coccifera and R. officinalis over C. albidus and U. parviflorus (Rodriguez-Ramirez et al. 2017). The current species distribution across the Mediterranean region suggests that the conditions should become even more arid (i.e. with an annual precipitation between 100 and $400 \mathrm{~mm}$ ) and only $R$. officinalis would be able to persist among the four dominant shrub species studied here (T. Gauquelin, pers. comm.; Rhanem 2009). This would mark a fundamental ecosystem state shift with a probably completely different structure and functioning of soil microbial communities. The few plant diversity effects we found and the impacts of reduced precipitation are more difficult to interpret. Collectively with previous experiments from the same study site, our data show that the relationships between shrub diversity and microbial functioning seem highly dependent on the stage of litter decomposition and the evenness of different litter types contributing to the litter layer. Due to these dynamic changes, the overall impact of shrub diversity on the activity and metabolic diversity of soil microbial communities are presently difficult to predict.

\section{Acknowledgements}

This study was funded by the French National Research Agency (ANR) as part of the CLIMED research project (contract "ANR-09-CEP-007") and through a grant of Aleppo University, Syria to AH. We are grateful to all the colleagues from CEFE UMR 5175 and from IMBE UMR 7263 who contributed to the set-up and maintenance of the rain exclusion experiment in Marseille. We especially thank JeanFrançois David and Mathieu Coulis for soil sampling, Natalia Rodriguez-Ramirez for plant survey, JeanPhilippe Mevy (IMBE) and Cyril Bernard (CEFE) for meteorological data, and Alexandre Clet for his help during MicroResp ${ }^{\mathrm{TM}}$ analyses. Litter traits and MicroResp ${ }^{\mathrm{TM}}$ analyses were performed at the PlateForme d'Analyses Chimiques en Ecologie, LabEx Centre Méditerranéen de l'Environnement et de la Biodiversité, with the help of Bruno Buatois and Clémence Dufresne. Dissolved Carbon and Nitrogen analyses were performed at the Eco\&Sols BioSolTrop lab (LabEx Centre Méditerranéen de l'Environnement et de la Biodiversité, Montpellier) with the help of Jean Larvy Delarivière. We kindly 
thank Sylvain Coq for pre-submission review and comments on the manuscript. Finally, we are grateful to the two anonymous referees for their helpful comments.

\section{References}

Allison SD, Martiny JBH (2008) Resistance, resilience, and redundancy in microbial communities. Proc Natl Acad Sci USA 105:11512-11519. https://doi.org/10.1073/pnas.0801925105

Ahlström A, Raupach MR, Schurgers G, Smith B, Arneth A, Jung M, Reichstein M, Canadell JG, Friedlingstein P, Jain AK, Kato E, Poulter B, Sitch S, Stocker BD, Viovy N, Wang YP, Wiltshire A, Zaehle S, Zeng N (2015) The dominant role of semi-arid ecosystems in the trend and variability of the land $\mathrm{CO}_{2}$ sink Science 348:895-899. https://doi.org/10.1126/science.aaa1668

Augusto L, De Schrijver A, Vesterdal L, Smolander A, Prescott C, Ranger J (2015) Influences of evergreen gymnosperm and deciduous angiosperm tree species on the functioning of temperate and boreal forests. Biol Rev 90: 444-466. https://doi.org/10.1111/brv.12119

Bessler H, Temperton VM, Roscher C, Buchmann N, Schmid B, Schulze E-D, Weisser WW, Engels C (2009) Aboveground overyielding in grassland mixtures is associated with reduced biomass partitioning to belowground organs. Ecology 90:1520-1530. https://doi.org/10.1890/08-0867.1

Bonanomi G, Incerti G, Antignami V, Capodilupo M, Mazzoleni S (2010) Decomposition and nutrient dynamics in mixed litter of Mediterranean species. Plant Soil 331:481-496. https://doi.org/10.1007/s11104-009-0269-6

Bond-Lamberty B; Thomson A (2010) A global database of soil respiration data. Biogeosciences 2010, 7, 1915-1926. https://doi.org/10.5194/bg-7-1915-2010

Bonkowski M, Roy J (2005) Soil microbial diversity and soil functioning affect competition among grasses in experimental microcosms. Oecologia 143:232-240. https://doi.org/10.1007/s00442$\underline{004-1790-1}$ 
Campbell CD, Cameron CM, Bastias BA, Chen C, Cairney JWG (2008) Long term repeated burning in a wet sclerophyll forest reduces fungal and bacterial biomass and responses to carbon substrates. Soil Biol Biochem 40:2246-2252. https://doi.org/10.1016/j.soilbio.2008.04.020

Carbone MS, Still CJ, Ambrose AR, Dawson TE, Williams AP, Boot CM, Schaeffer SM, Schimel JP (2011) Seasonal and episodic moisture controls on plant and microbial contributions to soil respiration. Oecologia 167:265-278. https://doi.org/10.1007/s00442-011-1975-3

Carney KM, Matson PA (2005) Plant communities, soil microorganisms, and soil carbon cycling: Does altering the world belowground matter to ecosystem functioning? Ecosystems, 8, 928-940. https://doi.org/10.1007/s10021-005-0047-0

Cerabolini B, Pierce S, Luzzaro A, Ossola A (2010) Species evenness affects ecosystem processes in situ via diversity in the adaptive strategies of dominant species. Plant Ecol 207:333-345. https://doi.org/10.1007/s11258-009-9677-1

Chapman SK, Newman GS (2010) Biodiversity at the plant-soil interface: microbial abundance and community structure responding to litter mixing. Oecologia 162:763-769. https://doi.org/10.1007/s00442-009-1498-3

Chen C, Chen HYH, Chen X, Huang Z (2019) Meta-analysis shows positive effects of plant diversity on microbial biomass and respiration. Nature communications 10:1332. https://doi.org/10.1038/s41467-019-09258-y

Chodak M, Klimek B, Azarbad H, Jazwa M (2015) Functional diversity of soil microbial communities under Scots pine, Norway spruce, silver birch and mixed boreal forests. Pedobiologia 58:81-88. https://doi.org/10.1016/j.pedobi.2015.04.002

Chomel M, Fernandez C, Bousquet-Mélou A, Gers C, Monnier Y, Santonja M, Gauquelin T, Gros R, Lecareux C, Baldy V (2014). Secondary metabolites of Pinus halepensis alter decomposer organisms and litter decomposition during afforestation of abandoned agricultural zones. Journal of Ecology 102:411-424. https://doi.org/10.1111/1365-2745.12205

Conti G, Diaz S (2013) Plant functional diversity and carbon storage - an empirical test in semi-arid forest ecosystems. J Ecol 101:18-28. https://doi.org/10.1111/1365-2745.12012 
Coulis M., Hättenschwiler S, Fromin N, David J-F (2013) Macroarthropod-microorganism interactions during the decomposition of Mediterranean shrub litter at different moisture levels. Soil Biology \& Biochemistry 64: 114-121. https://doi.org/10.1016/j.soilbio.2013.04.012

Coulis M, Fromin N, David J-F, Gavinet J, Clet A, Devidal S, Roy J, Hättenschwiler S (2015) Functional dissimilarity across trophic levels as a driver of soil processes in a Mediterranean decomposer system exposed to two moisture levels. Oikos 124:1304-1316. https://doi.org/10.1111/oik.01917

Crawley MJ (2013) The R book. John Wiley \& Sons Inc. ISBN: 978-0-470-97392-9

Creamer RE, Stone D, Berry P, Kuiper I (2016) Measuring respiration profiles of soil microbial communities across Europe using MicroResp ${ }^{\mathrm{TM}}$ method. Appl Soil Ecol 97:36-43. https://doi.org/10.1016/j.apsoil.2015.08.004

Curiel Yuste J, Fernandez-Gonzalez AJ, Fernandez-Lopez M, Ogaya R, Peñuelas J, Sardans J, Lloret F (2014) Strong functional stability of soil microbial communities under semiarid Mediterranean conditions and subjected to long-term shifts in baseline precipitation. Soil Biol Biochem 69:223233. https://doi.org/10.1016/j.soilbio.2013.10.045

Cutler DR, Edwards TC, Beard KH, Cutler A, Hess KT, Gibson J, Lawler JJ (2007) Random forests for classification in ecology. Ecology 88:2783-2792. https://doi.org/10.1890/07-0539.1

De Dato GD, De Angelis P, Sirca C, Beier C (2010) Impact of drought and increasing temperatures on soil $\mathrm{CO}_{2}$ emissions in a Mediterranean shrubland (gariga). Plant Soil 327:153-166. https://doi.org/10.1007/s11104-009-0041-y

De Deyn G (2013) Ecosystem carbon and soil biodiversity. In Lal R, Lorenz K, Hüttl R, Schneider B, von Braun J (Eds) Ecosystem services and carbon sequestration in the biosphere, Springer, Dordrecht. https://doi.org/10.1007/978-94-007-6455-2_7

De Micco V., Aronne G. (2012) Morpho-anatomical traits for plant adaptation to drought. In: Aroca R. (ed) Plant responses to drought stress. Springer, Berlin, Heidelberg. https://doi.org/10.1007/978$\underline{3-642-32653-0 \quad 2}$ 
Díaz S, Lavorel S, de Bello F, Quétier F, Grigulis K, Robson TM (2007) Incorporating plant functional diversity effects in ecosystem service assessments. Proc Nat Acad Sci USA 104:20684-20689. https://doi.org/10.1073/pnas.0704716104

Eisenhauer N, Dobles T, Cesarz S, Hobbie SE, Meyer RJ, Worm K, Reich PB (2013) Plant diversity effects on soil food webs are stronger than those of elevated $\mathrm{CO}_{2}$ and $\mathrm{N}$ deposition in a long-term grassland experiment. Proc Nat Acad Sci USA 110:6889-6894. https://doi.org/10.1073/pnas.1217382110

Esch EH, Lipson D, Cleland EE (2017) Direct and indirect effects of shifting rainfall on soil microbial respiration and enzyme activity in a semi-arid system. Plant Soil 411:333-346. https://doi.org/10.1007/s11104-016-3027-6

Evans SE, Wallenstein MD (2012) Soil microbial community response to drying and rewetting stress: does historical precipitation regime matter? Biogeochemistry 109:101-116. https://doi.org/10.1007/S10533-011-9638-3

Eviner VT, Chapin III FS (2003) Functional matrix: a conceptual framework for predicting multiple plant effects on ecosystem processes. Annu Rev Ecol Evol Syst 34:455-485. https://doi.org/10.1146/annurev.ecolsys.34.011802.132342

Fioretto A, Papa S, Pellegrino A, Ferrigno A (2009) Microbial activities in soils of a Mediterranean ecosystem in different successional stages. Soil Biol Biochem 41:2061-2068. https://doi.org/10.1016/j.soilbio.2009.07.010

Fry EL, Manning P, Allen DGP, Hurst A, Everwand G, Rimmler M, Power SA (2013) Plant functional group composition modifies the effects of precipitation change on grassland ecosystem function. PLoS ONE 8:e57027. https://doi.org/10.1371/journal.pone.0057027

Garcia C, Roldan A, Hernandez T (2005) Ability of different plant species to promote microbiological $\begin{array}{lllll}\text { processes } & \text { in } & \text { semiarid } & \text { soil. } & \text { Geoderma }\end{array}$ https://doi.org/10.1016/j.geoderma.2004.04.013 
Garnier E, Cortez J, Billes G, Navas M, Roumet C, Debussche M, Laurent G, Blanchard A, Aubry D, Bellmann A, Neill C, Toussaint J (2004) Plant functional markers capture ecosystem properties during secondary succession. Ecology 85:2630-2637. https://doi.org/10.1890/03-0799

Gessner MO, Swan CM, Dang CK, Mckie BG, Bardgett RD, Wall DH, Hättenschwiler S (2010) Diversity meets decomposition. Trends Ecol Evol 25:372-380. https://doi.org/10.1016/j.tree.2010.01.010

Grime J (1998) Benefits of plant diversity to ecosystems: immediate, filter and founder effects. J Ecol 86:902-910. https://doi.org/10.1046/j.1365-2745.1998.00306.x

Hawkes CV, Keitt TH (2015) Resilience vs. historical contingency in microbial responses to environmental change. Ecol Lett 18:612-625. https://doi.org/10.1111/ele.12451

Hillebrand H, Bennett DM, Cadotte MW (2008) Consequences of dominance: A review of evenness effects on local and regional ecosystem processes. Ecology 89:1510-1520. https://doi.org/10.1890/07-1053.1

Hooper DU, Chapin FS, Ewel JJ, Hector A, Inchausti P, Lavorel S, Lawton JH, Lodge DM, Loreau M, Naeem S, Schmid B, Setala H, Symstad AJ, Vandermeer J, Wardle DA (2005) Effects of biodiversity on ecosystem functioning: A consensus of current knowledge. Ecol Monograph 75:335. https://doi.org/10.1890/04-0922

Joly F-X, Fromin N, Kiikilä O, Scherer-Lorenzen M, Hättenschwiler S (2016) Diversity of leaf litter leachates from temperate forest trees and its consequences for soil microbial activity. Biogeochemistry 129:373-388. https://doi.org/10.1007/s10533-016-0239-z

Joly F-X, Milcu A, Scherer-Lorenzen M, Jean LK, Bussotti F, Dawud SM, Muller S, Pollastrini M, Raulund-Rasmussen K, Vesterdal L, Hättenschwiler S (2017) Tree species diversity affects decomposition through modified micro-environmental conditions across European forests. New Phytol 214: 1281-1293. https://doi.org/10.1111/nph.14452

Liaw A and Wiener M (2002) Classification and Regression by randomForest. R News 2/3:18-22 
Lionello, P. \& Scarascia, L. (2018) The relation between climate change in the Mediterranean region and global warming. Reg Environ Change 18: 1481. https://doi.org/10.1007\%2Fs10113-018$\underline{1290-1}$

Lucas-Borja ME, Candel D, Jindo K, Moreno JL, Andrés M, Bastida F (2012) Soil microbial community structure and activity in monospecific and mixed forest stands, under Mediterranean humid conditions. Plant Soil 354:359-370. https://doi.org/10.1007/s11104-011-1072-8

Massaccesi L, Bardgett RD, Agnelli A, Ostle N, Wilby A, Orwin KH (2015) Impact of plant species evenness, dominant species identity and spatial arrangement on the structure and functioning of soil microbial communities in a model grassland. Oecologia 177:747-759. https://doi.org/10.1007/s00442-014-3135-z

Maestre FT, Bowker MA, Cantón Y, Castillo-Monroy AP, Cortina J, Escolar C, Escudero A, Lázaro R, Martínez I (2011) Ecology and functional roles of biological soil crusts in semi-arid ecosystems of Spain. J Arid Environ 75:1282-1291. https://doi.org/10.1016/j.jaridenv.2010.12.008

McIntyre S, Lavorel S, Landsberg J, Forbes TDA (2015) Disturbance response in vegetation - towards a global perspective on functional traits. J Veg Sci 10:621-630. https://doi.org/10.2307/3237077

Milcu A, Eisenhauer N, Scheu S, Thebault E (2010). Plant diversity enhances the reliability of belowground processes. Soil Biol Biochem 42, 2102-2110. https://doi.org/10.1016/j.soilbio.2010.08.005

Montes N, Maestre FT, Ballini C, Baldy V, Gauquelin T, Planquette M, Greff S, Dupouyet S, Perret JB (2008) On the relative importance of the effects of selection and complementarity as drivers of diversity-productivity relationships in Mediterranean shrublands. Oikos 117:1345-1350. https://doi.org/10.1111/j.0030-1299.2008.16910.x

Navratilova D, Tlaskalova P, Kohout P, Drevojan P, Fajmon K, Chytry M, Baldrian P (2019) Diversity of fungi and bacteria in species-rich grassland increases with plant diversity in shoots but not in roots and soil. FEMS Microbiol Ecol 95. https://doi.org/10.1093/femsec/fiy208 
Orwin KA, Wardle DA, Greenfield LG (2006) Context-dependent changes in the resistance and resilience of soil microbes to an experimental disturbance for three primary plant chronosequences. Oïkos 112:196-208. https://doi.org/10.1111/j.0030-1299.2006.13813.x

Pailler A, Vennetier M, Torre F, Ripert C, Guiral D (2014) Forest soil microbial functional patterns and response to a drought and warming event: Key role of climate-plant-soil interactions at a regional scale. Soil Biol Biochem 70:1-4. https://doi.org/10.1016/j.soilbio.2013.12.003

Pan X, Berg MP, Butenschoen O, Murray PJ, Bartish IV, Cornelissen JHC, Dong M, Prinzing A. (2015) Larger phylogenetic distances in litter mixtures: lower microbial biomass and higher $\mathrm{C} / \mathrm{N}$ ratios but equal mass loss. Proc. R. Soc. B 282:20150103. https://doi.org/10.1098/rspb.2015.0103

Peñuelas J, Sardans J, Filella I, Estiarte M, Llusia J, Ogaya R, Carnicer J, Bartrons M, Rivas-Ubach A, Grau O, Peguero G, Margalef O, Pla S, Stefanescu C, Asensio D, Preece C, Lei L, Verger A, Rico L, Terradas J (2017) Assessment of the impacts of climate change on Mediterranean terrestrial ecosystems based on data from field experiments and long-term monitored field gradients in Catalonia. Environ Exp Bot. 152:49-59. https://10.1016/j.envexpbot.2017.05.012

Pires APF, Srivastava DS, Marino NAC, MacDonald AMM, Figueiros-Barros MP, Frjalla VF (2018) Interactive effects of climate change and biodiversity loss on ecosystem functioning. Ecology 99:1203-1213. https://doi.org/10.1002/ecy.2202

Polade SD, Pierce DW, Cayan DR, Gershunov A, Dettinger MD (2014) The key role of dry days in changing regional climate and precipitation regimes. Sci Rep-UK 4:4364. https://doi.org/10.1038/srep04364

Poulter B, Franck F, Ciais P, Myneni RB, ANdela N, BI J, Broquet G, Canadell JG, Chevallier F, Liu YY, Running SW, Sitch S, van der Werf GR (2014) Contribution of semi-arid ecosystems to interannual variability of the global carbon cycle. Nature 509:600-603. https://doi.org/10.1038/nature13376

Rhanem M (2009) L'alfa (Stipa tenacissima L.) dans la plaine de Midelt (haut bassin versant de la Moulouya, Maroc) - Éléments de climatologie », Physio-Géo, Volume 3. https://doi.org/10.4000/physio-geo.696 
Rodriguez-Ramirez N, Santonja M, Baldy V, Ballini C, Montès N (2017) Shrub species richness decreases negative impacts of drought in a Mediterranean ecosystem. J Veg Sci 28:985-996. https://doi.org/10.1111/jvs.12558

Santonja M, Fernandez C, Gauquelin T, Baldy V (2015) Climate change effects on litter decomposition: drier climate leads to a strong decrease of litter mixture interactions. Plant Soil 393:69-82. https://doi.org/10.1007/s11104-015-2471-z

Santonja M, Fernandez C, Gers C, Proffit M, Gauquelin T, Reiter I, Cramer W, Baldy V (2017a). Plant litter mixture partly mitigates the negative effects of extended drought on soil biota and litter decomposition in a Mediterranean oak forest. Journal of Ecology 105:801-815. https://doi.org/10.1111/1365-2745.12711

Santonja M, Rancon A, Fromin N, Baldy V, Hättenschwiler S, Fernandez C, Montes N, Mirleau P (2017b) Plant litter diversity increases microbial abundance, fungal diversity, and carbon and nitrogen cycling in a Mediterranean shrubland. Soil Biol Biochem 111:124-134. https://doi.org/10.1016/j.soilbio.2017.04.006

Santonja M, Foucault Q, Rancon A, Baldy V, Gauquelin T, Fernandez C, Mirleau P (2018) Contrasting responses of bacterial and fungal communities to plant litter diversity in a Mediterranean oak forest. Soil Biol Biochem 125:27-36. https://doi.org/10.1016/j.soilbio.2018.06.020

Santonja M, Milcu A, Fromin N, Rancon A, Shihan A, Fernandez C, Baldy V, Hättenschwiler S (2019) Temporal shifts in plant diversity effects on carbon and nitrogen dynamics during litter decomposition in a Mediterranean shrubland exposed to reduced precipitation. Ecosystems 22:939-954. https://doi.org/10.1007/s10021-018-0315-4

Sardans J, Peñuelas J, Estiarte M (2008) Changes in soil enzymes related to C and N cycle and in soil C and $\mathrm{N}$ content under prolonged warming and drought in a Mediterranean shrubland. Appl Soil Ecol 39: 223-235. https://doi.org/10.1016/j.apsoil.2007.12.011

Sardans J, Peñuelas J (2013) Plant-soil interactions in Mediterranean forest and shrublands: impacts of climatic change. Plant Soil 365:1-33. https://doi.org/10.1007/s11104-013-1591-6 
Saura-Mas S, Estiarte M, Peñuelas J, Lloret F (2012) Effects of climate change on leaf litter decomposition across post-fire plant regenerative groups. Environ Exp Bot 77: 274-282. https://doi.org/10.1016/j.envexpbot.2011.11.014

Scherber C, Eisenhauer N, Weisser WW, Schmid B, et al. (2010) Bottom-up effects of plant diversity on multitrophic interactions in a biodiversity experiment. Nature 468:553-556. https://doi.org/10.1038/nature09492

Schimel JP (2018) Life in dry soils: Effects of drought on soil microbial communities and processes. Annu Rev Ecol Evol Syst 49:409-432. https://doi.org/10.1146/annurev-ecolsys-110617-062614

Shihan A, Hättenschwiler S, Milcu A, Joly F-X, Santonja M, Fromin N (2017) Changes in soil microbial substrate utilization in response to altered litter diversity and precipitation in a Mediterranean shrubland. Biol Fertil Soil 53:171-185. https://doi.org/10.1007/s00374-016-1166-9

Steinauer K, Tilman D, Wragg PD, Cesarz S, Cowles JM, Pritsch K, Reich PB, Weisser WW, Eisenhauer N (2015) Plant diversity effects on soil microbial functions and enzymes are stronger than warming in a grassland experiment. Ecology 96:99-112. https://doi.org/10.1890/14-0088.1

Strecker T, Barnard RL, Niklaus PA, Scherer-Lorenzen M, Weigelt A, Scheu S, Eisenhauer N (2015) Effects of plant diversity, functional group composition, and fertilization on soil microbial properties in experimental grassland. PLoS ONE 10:e0125678. https://doi.org/10.1371/journal.pone.0125678

Thakur MV, Milcu A, Manning P, Niklaus PA, Roscher C, Power S, Reich PB, Scheu S, Tilman D, Ai F, Guo H, Ji R, Pierce S, Guerrero Ramirez N, Richter AN, Steinauer K, Strecker T, Vogel A, Eisenhauer N (2015) Plant diversity drives soil microbial biomass carbon in grasslands irrespective of global environmental change factors. Global Change Biol 21:4076-4085. https://doi.org/10.1111/gcb.13011

Tlàskal V, Vořiškovà J, Baldrian P (2016) Bacterial succession on decomposing leaf litter exhibits a specific occurrence pattern of cellulolytic taxa and potential decomposers of fungal mycelia. FEMS Microbiol Ecol 92/fiw177. https://doi.org/10.1093/femsec/fiw177

Venables WN, Ripley BD (2002) Modern applied statistics with S. Fourth Edition. Springer, New York. 
Vogel A, Fester T, Eisenhauer N, Scherer-Lorenzen M, Schmid B, Weisser WW, Weigelt A (2013) Separating drought effects from roof artifacts on ecosystem processes in a grassland drought experiment. PLoS ONE 8:e70997. https://doi.org/10.1371/journal.pone.0070997

Wang X-Y, Ge Y, Wang J (2017) Positive effects of plant diversity on soil microbial biomass and activity are associated with more root biomass production. J Plant Interact 12:533-541. https://doi.org/10.1080/17429145.2017.1400123

Ward SE, Orwin KH, Ostle NJ, Briones MJ, Thomson BC, Griffiths RI, Oakley S, Quirk H, Bardgett RD (2015) Vegetation exert a greater control on litter decomposition than climate warming in peatlands. Ecology 96:113-123. https://doi.org/10.1890/14-0292.1 


\section{Figures}

773 Fig. 1. Substrate-induced respiration rates (boxplots with lower and upper quartiles) on the 15 carbon

774

775

776

777

778

779

780

substrates, in control (light grey) and rain exclusion (dark grey) plots, in (a) May 2012 and (b) May 2014. Student t-tests did not reveal any significant difference in mean SIR rates between control and rain exclusion plots.

(a)

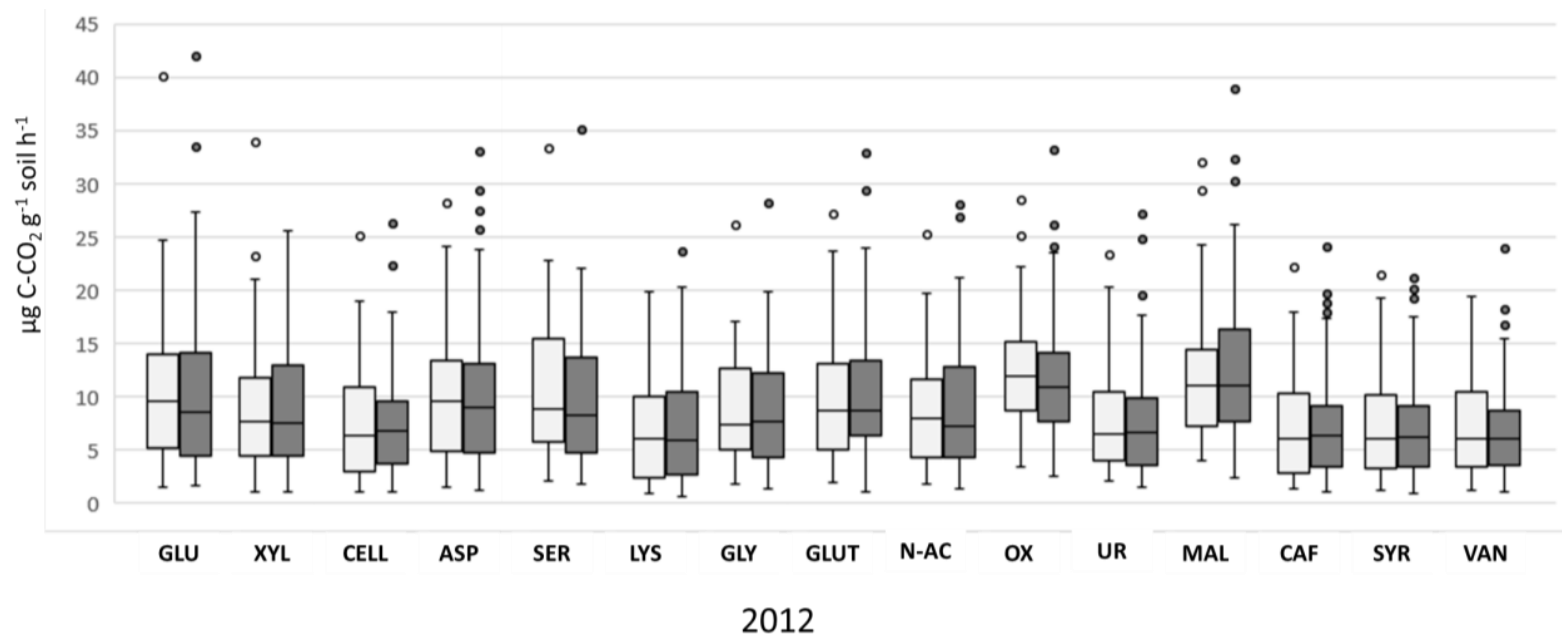

(b)

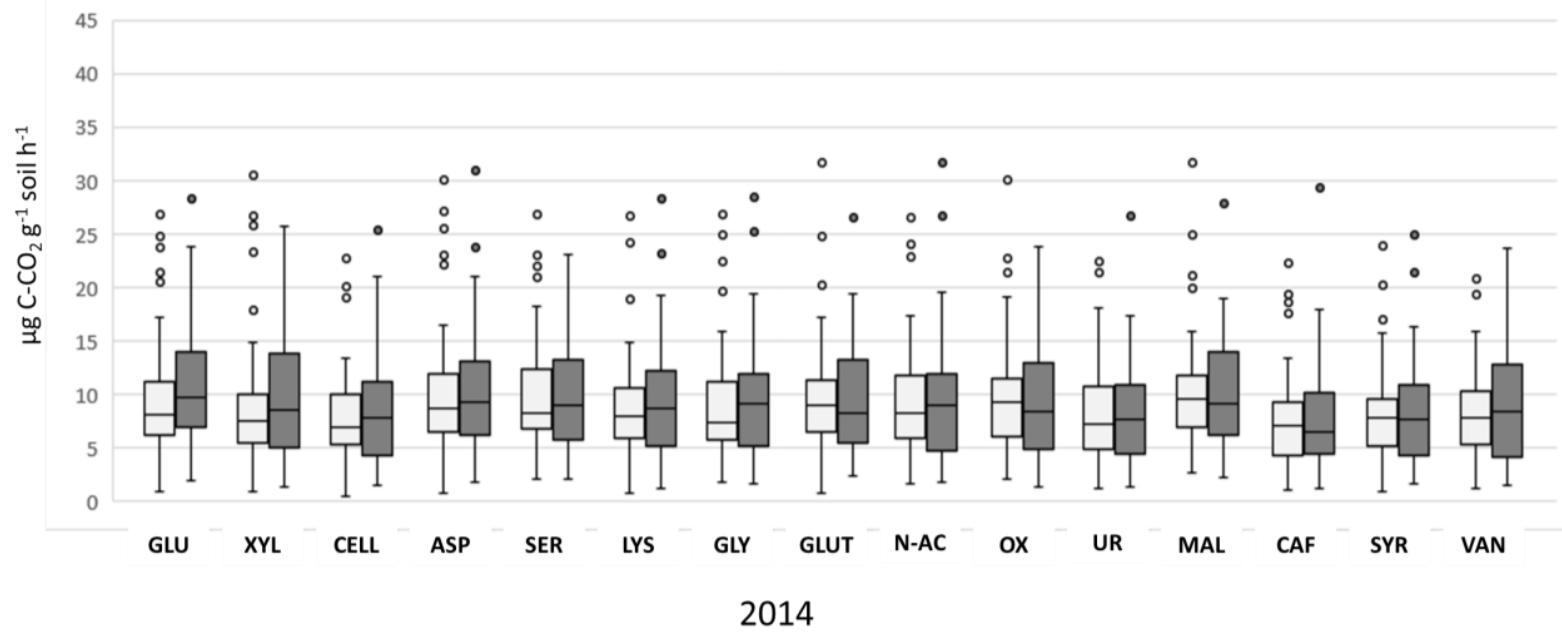


Fig. 2. Soil microbial catabolic (a) activity $(\log (\operatorname{sum} 15))$ and (b) diversity $\left(H^{\prime} m i c\right)$ as a function of

783

784

785

786

787

(a)

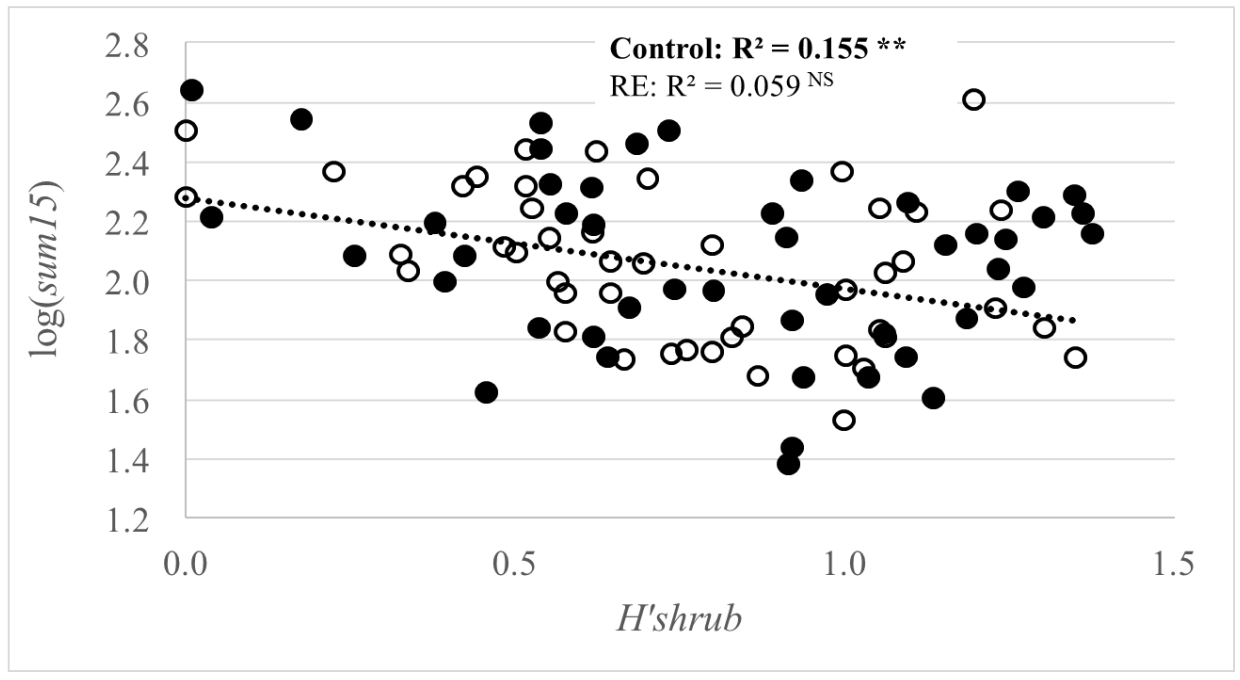

(b)

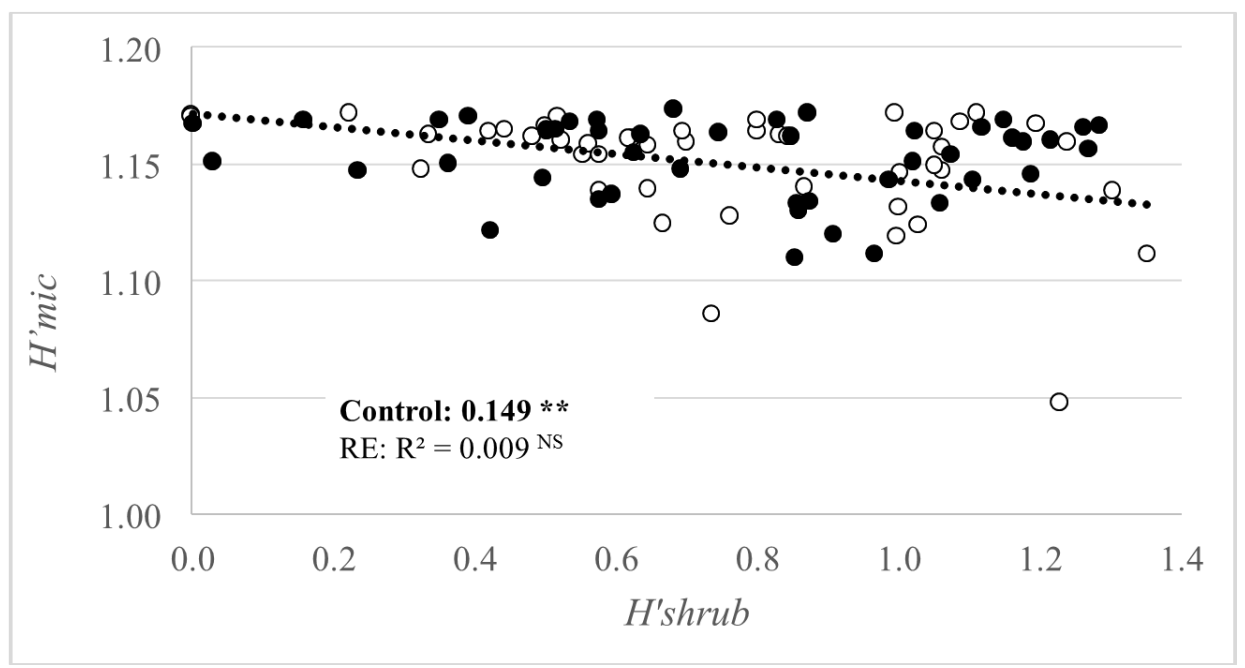
May 2014.

\section{)} dominant shrub species diversity (H'shrub) in control (light grey circles) and rain exclusion (RE, dark grey circles) plots in May 2012. Significant linear relationships in control plots are indicated with dotted lines. Adjusted $\mathrm{R}^{2}$ and associated $\mathrm{p}$-values are indicated. No significant relationship was observed in 
Table 1. Output of multiple linear models testing for the effects of rain exclusion treatment (RE), plot792 specific shrub community parameters (total shrub cover ShrubCov and shrub diversity H'shrub) and 793 their interactions on the soil microbial global metabolic activity (sum15) and metabolic diversity (H'mic) 794 in 2012 (a) and 2014 (b). Plot-specific soil characteristics (Soil-PCA) were included as co-variable. We

795

801

\begin{tabular}{|c|c|c|c|c|c|c|c|c|}
\hline & & D.f & S.sq & M.sq & F-value & $\mathrm{p}$-value & $\begin{array}{c}\text { All } \\
\mathrm{R}^{2}(\mathrm{AIC})\end{array}$ & $\begin{array}{c}\text { MPM } \\
\mathbf{R}^{2}(\mathrm{AIC})\end{array}$ \\
\hline \multicolumn{9}{|l|}{ (a) 2012} \\
\hline \multirow{4}{*}{ sum15 } & Soil-PCA & 1 & 2.838 & 2.8379 & 71.195 & $<0.001 * * *$ & \multirow{4}{*}{$\begin{array}{c}0.51 \\
(-289.35)\end{array}$} & \multirow{4}{*}{$\begin{array}{c}0.49 \\
(-292.55)\end{array}$} \\
\hline & ShrubCov & 1 & 0.249 & 0.2488 & 6.243 & $0.014 * \uparrow$ & & \\
\hline & H'shrub & 1 & 0.290 & 0.2900 & 7.275 & $0.008 * * \downarrow$ & & \\
\hline & Residuals & 88 & 3.508 & 0.0399 & & & & \\
\hline \multirow{5}{*}{ H'mic } & Soil-PCA & 1 & 0.005439 & 0.005439 & 15.613 & $>0.001 * * *$ & \multirow{5}{*}{$\begin{array}{c}0.27 \\
(-728.65)\end{array}$} & \multirow{5}{*}{$\begin{array}{c}0.22 \\
(-727.67)\end{array}$} \\
\hline & RE & 1 & 0.000050 & 0.000050 & 0.144 & 0.705 & & \\
\hline & H'shrub & 1 & 0.001325 & 0.001325 & 3.803 & $0.044 ' \downarrow$ & & \\
\hline & $\mathrm{RE} \times$ H'shrub & 1 & 0.001939 & 0.001939 & 5.567 & $\begin{array}{c}\mathbf{0 . 0 2 1} * \\
(\mathbf{C}=* * \downarrow \\
\left.\mathbf{R E}^{\mathrm{NS}} \downarrow\right)\end{array}$ & & \\
\hline & Residuals & 87 & 0.030306 & 0.000348 & & & & \\
\hline \multicolumn{9}{|l|}{ (b) 2014} \\
\hline \multirow{3}{*}{ sum15 } & Soil-PCA & 1 & 0.408 & 0.4077 & 7.046 & $<0.01 * *$ & \multirow[t]{3}{*}{$\begin{array}{c}0.18 \\
(-238.44)\end{array}$} & \multirow[t]{3}{*}{$\begin{array}{c}0.16 \\
(-244.97)\end{array}$} \\
\hline & ShrubCov & 1 & 0.545 & 0.5448 & 9.415 & $0.003 * * \uparrow$ & & \\
\hline & Residuals & 84 & 4.861 & 0.0579 & & & & \\
\hline \multirow{5}{*}{ H'mic } & Soil-PCA & 1 & 0.0008 & 0.0008 & 7.269 & $0.009 * *$ & \multirow{5}{*}{$\begin{array}{c}0.21 \\
(-787.63)\end{array}$} & \multirow{5}{*}{$\begin{array}{c}0.21 \\
(-791.49)\end{array}$} \\
\hline & RE & 1 & 0.00005 & 0.00005 & 0.484 & 0.489 & & \\
\hline & ShrubCov & 1 & 0.0009 & 0.0009 & 8.832 & $0.004 * * \uparrow$ & & \\
\hline & $\mathrm{RE} \times S h r u b C o v$ & 1 & 0.0005 & 0.0005 & 5.006 & $\begin{array}{c}\mathbf{0 . 0 2 8 *} \\
\left(\mathbf{C}=* * \uparrow, \mathbf{R E}^{\mathrm{NS}}\right)\end{array}$ & & \\
\hline & Residuals & 82 & 0.009 & 0.0001 & & & & \\
\hline
\end{tabular}
report the $R^{2}$ and AIC weight of the general model including all factors (All) and of the most parsimonious model (MPM, in bold). Only the variables retained in the most parsimonious models are reported (intercept $=$ none of variable was retained). $n=92$ and 87 plots in 2012 and 2014, respectively. $F$-value and associated significance of $p$-value (' $p<0.10 ; * p<0.05 ; * * p<0.01$; *** $p<0.001$ ) are reported. Arrows indicate the direction of the effect, and ${ }^{\mathrm{NS}}$ indicates non-significant effect of RE within a given treatment. 
Table 2. Output of multiple linear models testing for the effects of rain exclusion treatment (RE) and

805 plot-specific shrub community parameters (total shrub cover, ShrubCov, and relative cover of C. albidus

806

807

808

809

810

811

812

813

814

815

\begin{tabular}{|c|c|c|c|c|c|c|c|c|}
\hline & & D.f & S.sq & M.sq & F-value & p-value & $\begin{array}{c}\text { All } \\
\mathrm{R}^{2}(\mathrm{AIC})\end{array}$ & $\begin{array}{c}\text { MPM } \\
\mathbf{R}^{2}(\mathrm{AIC})\end{array}$ \\
\hline \multicolumn{9}{|l|}{ (a) 2012} \\
\hline \multirow{3}{*}{ sum15 } & Soil-PCA & 1 & 2.828 & 2.838 & 85.32 & $<0.001 * * *$ & \multirow{3}{*}{$\begin{array}{c}0.60 \\
(-299.69)\end{array}$} & \multirow{3}{*}{$\begin{array}{c}0.57 \\
(-310.16)\end{array}$} \\
\hline & $Q c \%$ & 1 & 1.087 & 1.087 & 32.66 & $<0.001 * * * \uparrow$ & & \\
\hline & Residuals & 89 & 2.960 & $\mathbf{0 . 0 3 3}$ & & & & \\
\hline \multirow{4}{*}{ H'mic } & Soil-PCA & 1 & 0.005 & 0.005 & 18.309 & $<0.001 * * *$ & \multirow{4}{*}{$\begin{array}{c}0.37 \\
(-734.11)\end{array}$} & \multirow{4}{*}{$\begin{array}{c}0.33 \\
(-743.28)\end{array}$} \\
\hline & $Q c \%$ & 1 & 0.007 & 0.007 & 22.070 & $<0.001 * * * \uparrow$ & & \\
\hline & $\widetilde{U p} \%$ & 1 & 0.001 & 0.001 & 3.109 & $0.081^{\prime} \uparrow$ & & \\
\hline & Residuals & 88 & 0.026 & 0.0003 & & & & \\
\hline \multicolumn{9}{|l|}{ (b) 2014} \\
\hline \multirow{4}{*}{ sum15 } & ShrubCov & 1 & 0.599 & 0.599 & 12.911 & $<0.001 * * * \uparrow$ & \multirow{4}{*}{$\begin{array}{c}0.43 \\
(-261.67)\end{array}$} & \multirow{4}{*}{$\begin{array}{c}0.34 \\
(-263.23)\end{array}$} \\
\hline & $\boldsymbol{R o} \%$ & 1 & 1.150 & 1.1504 & 24.795 & $<0.001 * * * \downarrow$ & & \\
\hline & $U p \%$ & 1 & 0.213 & 0.2131 & 4.593 & $\mathbf{0 . 0 3 5}^{*} \uparrow$ & & \\
\hline & Residuals & 83 & 3.851 & 0.046 & & & & \\
\hline \multirow{5}{*}{ H'mic } & Soil-PCA & 1 & 0.0008 & 0.0008 & 7.269 & $0.009 * *$ & \multirow{5}{*}{$\begin{array}{c}0.25 \\
(-784.42)\end{array}$} & \multirow{5}{*}{$\begin{array}{c}0.21 \\
(-791.49)\end{array}$} \\
\hline & RE & 1 & 0.00005 & 0.00005 & 0.484 & 0.489 & & \\
\hline & ShrubCov & 1 & 0.0009 & 0.0009 & 8.832 & $0.004 * * \uparrow$ & & \\
\hline & $\mathbf{R E} \times \operatorname{ShrubCov}$ & 1 & 0.0005 & 0.0005 & 5.006 & $\begin{array}{c}\mathbf{0 . 0 2 8} * \\
(\mathbf{C}=* * \uparrow, \\
\mathbf{R E}=\mathbf{n o n} \uparrow)\end{array}$ & & \\
\hline & Residuals & 82 & 0.009 & 0.0001 & & & & \\
\hline
\end{tabular}
(Ca\%), Q. coccifera (Qc\%), R. officinalis (Ro\%) and U. parviflorus $(U p \%))$ and their interactions on the soil microbial global metabolic activity (sum15) and metabolic diversity (H'mic) in 2012 (a) and 2014 (b). Plot-specific soil characteristics (Soil-PCA) were included as co-variable. We report the $R^{2}$ and AIC weight of the general model including all factors (All) and of the most parsimonious model (MPM, in bold). Only the variables retained in the most parsimonious models are reported (intercept $=$ none of variable was retained). $n=92$ and 87 plots in 2012 and 2014, respectively. $F$-value and associated significance of $p$-value (' $p<0.10 ; * p<0.05$; ** $p<0.01$; *** $p<0.001$ ) are reported. Arrows indicate the direction of the effect. 
817 Table 3. Outputs of multiple linear models testing for the effects of rain exclusion treatments (RE) and

818 plot-specific shrub community parameters (total shrub cover, ShrubCov, and leaf litter aggregated traits,

819 aTraits), and their interactions on soil global metabolic activity (sum15) and metabolic diversity (H'mic)

820 in 2012 (a) and 2014 (b). Plot-specific soil characteristics (Soil-PCA) were included as co-variable. Only

821 the variables retained in the most parsimonious models are reported (intercept $=$ none of variable was

822 retained). We report the $R^{2}$ and AIC weight of the general model including all factors (All) and of the

823 most parsimonious model (MPM, in bold). $n=92$ and 87 plots in 2012 and 2014, respectively. $F$-value

824 and associated significance of $p$-value ( $p<0.10$; $*<<0.05$; ** $p<0.01$; *** $p<0.001)$ are reported.

825 Arrows indicate the direction of the effect.

826

\begin{tabular}{|c|c|c|c|c|c|c|c|c|}
\hline & & D.f & S.sq & M.sq & $F$-value & $p$-value & $\begin{array}{c}\text { All } \\
R^{2} \text { (AIC) }\end{array}$ & $\begin{array}{c}\text { MPM } \\
R^{2} \text { (AIC) }\end{array}$ \\
\hline \multicolumn{9}{|l|}{ (a) 2012} \\
\hline \multirow{4}{*}{ sum15 } & Soil-PCA & 1 & 2.838 & 2.838 & 86.638 & $<0.001 * * *$ & \multirow{4}{*}{$\begin{array}{c}0.59 \\
(-300.98)\end{array}$} & \multirow{4}{*}{$\begin{array}{c}0.58 \\
(-310.61)\end{array}$} \\
\hline & aPhenol & 1 & 0.884 & 0.884 & 26.973 & $<0.001 * * * \uparrow$ & & \\
\hline & $a T D N$ & 1 & 0.281 & 0.281 & 8.566 & $0.004 * * \uparrow$ & & \\
\hline & Residuals & 88 & 2.883 & 0.033 & & & & \\
\hline \multirow{3}{*}{$H^{\prime} m i c$} & Soil-PCA & 1 & 0.005 & 0.005 & 18.47 & $<0.001 * * *$ & \multirow{3}{*}{$\begin{array}{c}0.36 \\
(-735.87)\end{array}$} & \multirow{3}{*}{$\begin{array}{c}\mathbf{0 . 3 3} \\
(-\mathbf{7 4 5 . 0 2})\end{array}$} \\
\hline & $a N$ & 1 & 0.007 & 0.007 & 25.15 & $<0.001 * * * \uparrow$ & & \\
\hline & Residuals & 89 & 0.026 & 0.0003 & & & & \\
\hline \multicolumn{9}{|l|}{ (b) 2014} \\
\hline \multirow{4}{*}{ sum15 } & ShrubCov & 1 & 0.599 & 0.599 & 13.25 & $<0.001 * * * \uparrow$ & \multirow{4}{*}{$\begin{array}{c}0.39 \\
(-258.21)\end{array}$} & \multirow{4}{*}{$\begin{array}{c}0.35 \\
(-265.48)\end{array}$} \\
\hline & $a T D N$ & 1 & 0.974 & 0.974 & 21.54 & $<0.001 * * * \uparrow$ & & \\
\hline & $a N$ & 1 & 0.488 & 0.4875 & 10.78 & $0.002 * * \uparrow$ & & \\
\hline & Residuals & 83 & 3.753 & 0.045 & & & & \\
\hline \multirow{6}{*}{ H'mic } & Soil-PCA & 1 & 0.0008 & 0.0008 & 7.305 & $0.008 * *$ & \multirow{6}{*}{$\begin{array}{c}0.23 \\
(-783.97)\end{array}$} & \multirow{6}{*}{$\begin{array}{c}\mathbf{0 . 2 2} \\
(-790.98)\end{array}$} \\
\hline & ShrubCov & 1 & 0.0009 & 0.0009 & 8.926 & $0.004 * * \uparrow$ & & \\
\hline & $\mathrm{RE}$ & 1 & 0.00004 & 0.00004 & 0.436 & 0.511 & & \\
\hline & $a N$ & 1 & 0.0005 & 0.0005 & 0.573 & 0.451 & & \\
\hline & $\mathrm{RE} \times a N$ & 1 & 0.0006 & 0.0006 & 5.860 & $\begin{array}{c}\mathbf{0 . 0 1 8} * \\
(\mathbf{C}=* \uparrow, \mathbf{R E}=\text { non } \downarrow)\end{array}$ & & \\
\hline & Residuals & 81 & 0.009 & 0.0001 & & & & \\
\hline
\end{tabular}

827 
829 Table 4. Outputs of multiple linear models testing for the effects of rain exclusion treatments (RE) and 830 plot-specific shrub community parameters (total shrub cover, ShrubCov, and functional traits divergence 831 of the leaf litter fdTraits), and their interactions on soil microbial global metabolic activity (sum15) and 832 metabolic diversity (H'mic) in 2012 (a) and 2014 (b). Plot-specific soil characteristics (Soil-PCA) were 833 included as co-variable. Only the variables retained in the most parsimonious models are reported 834 (intercept $=$ none of variable was retained). We report the $R^{2}$ and AIC weight of the general model 835 including all factors (All) and of the most parsimonious model (MPM, in bold). $n=92$ and 87 plots in 8362012 and 2014, respectively. $F$-value and associated significance of $p$-value (' $p<0.10$; * $p<0.05$; ** $837 p<0.01 ; * * * p<0.001)$ are reported. Arrows indicate the direction of the effect.

838

\begin{tabular}{|c|c|c|c|c|c|c|c|c|}
\hline & & D.f & S.sq & M.sq & $F$-value & $p$-value & $\begin{array}{c}\text { All } \\
R^{2}(\mathrm{AIC})\end{array}$ & $\begin{array}{c}\text { MPM } \\
R^{2}(\mathrm{AIC})\end{array}$ \\
\hline \multicolumn{9}{|l|}{ (a) 2012} \\
\hline \multirow{4}{*}{ sum15 } & Soil-PCA & 1 & 2.838 & 2.838 & 82.97 & $<0.001 * * *$ & \multirow{4}{*}{$0.58(-295.71)$} & \multirow{4}{*}{$0.56(-306.62)$} \\
\hline & $f d D O C$ & 1 & 0.777 & 0.777 & 22.720 & $<0.001 * * * \downarrow$ & & \\
\hline & fdPhenol & 1 & 0.260 & 0.260 & 7.585 & $0.007 * * \uparrow$ & & \\
\hline & Residuals & 88 & 3.010 & 0.034 & & & & \\
\hline \multirow{4}{*}{ H'mic } & Soil-PCA & 1 & 0.005 & 0.005 & 18.389 & $<0.001 * * *$ & \multirow{4}{*}{$0.37(-733.06)$} & \multirow{4}{*}{$0.33(-743.68)$} \\
\hline & $f d D O C$ & 1 & 0.005 & 0.005 & 16.493 & $<0.001 * * * \downarrow$ & & \\
\hline & fdPhenol & 1 & 0.003 & 0.003 & 9.181 & $0.003 * * \uparrow$ & & \\
\hline & Residuals & 88 & 0.026 & 0.0003 & & & & \\
\hline \multicolumn{9}{|l|}{ (b) 2014} \\
\hline \multirow{5}{*}{ sum15 } & Soil-PCA & 1 & 0.408 & 0.408 & 8.099 & $0.006 * *$ & \multirow{5}{*}{$0.34(-247.8)$} & \multirow{5}{*}{$0.29(-255.18)$} \\
\hline & ShrubCov & 1 & 0.545 & 0.545 & 10.821 & $0.002 * * \uparrow$ & & \\
\hline & $f d N$ & 1 & 0.086 & 0.086 & 1.714 & 0.194 & & \\
\hline & fdPhenol & 1 & 0.646 & 0.646 & 12.838 & $<0.001 * * * \uparrow$ & & \\
\hline & Residuals & 82 & 4.128 & 0.050 & & & & \\
\hline \multirow{2}{*}{ H'mic } & Soil-PCA & 1 & 0.0008 & 0.0008 & 6.983 & $0.0098 * *$ & \multirow{2}{*}{$0.25(-781.9)$} & \multirow{2}{*}{$0.16(-789.9)$} \\
\hline & $\begin{array}{l}\text { ShrubCov } \\
\text { Residuals }\end{array}$ & $\begin{array}{c}\mathbf{1} \\
84\end{array}$ & $\begin{array}{c}\mathbf{0 . 0 0 0 9} \\
0.009\end{array}$ & $\begin{array}{l}\mathbf{0 . 0 0 0 9} \\
0.0001\end{array}$ & 8.533 & $0.005^{* * \uparrow}$ & & \\
\hline
\end{tabular}


